\title{
PWM方式マトリックスコンバータにおける 正弦波入出力電流を実現するための制御法に関する考察
}

\author{
正員 成 慶珉* 正員 中小路 元* \\ 正 員 佐藤 之彦**
}

\author{
A Control Method to Realize Sinusoidal Input and Output Current Waveforms \\ for Matrix Converters Based on PWM \\ KyungMin Sung*, Member, Hajime Nakakoji*, Member, Yukihiko Sato**, Member
}

\begin{abstract}
A matrix converter (MC) is a three-phase AC-to-AC direct converter without any energy storage requirement. It is expected to be a next generation converter by reason of possibilities of small size and high efficiency. At present, there are some problems to prevent it from being used practically. One of the problems is the distortion in the input current. The control methods proposed so far have not realized the enough reduction of the input current harmonics compared with conventional PWM rectifiers. As a solution to these problems, many approaches have been proposed.

In the present paper, an improved PWM method that can achieve both sinusoidal input and output currents simultaneously is considered. In this method, the MC is treated as a controlled voltage source viewed from the load side. On the other hand, it is treated as a controlled current source viewed from the line side. The proposed control method is based on the mathematical expression of the function of the PWM operation of MC. To improve the input current waveform, two line-to-line voltages of the three-phase line are used to control the output current. The output duty ratio of the two line-to-line voltages is utilized to improve the input current waveform without affecting the controllability of the output current. In addition, the compensation of the variations in the line voltage and the output current are introduced. In this way, the proposed method can realize the sinusoidal input and output currents. The effectiveness of the proposed control method is confirmed by some experimental results employing a laboratory prototype.
\end{abstract}

キーワード：マトリックスコンバータ, AC-AC 直接変換, PWM 制御, 正弦波入出力電流

Keywords: Matrix converters, AC-to-AC direct converter, PWM method, Sinusoidal input/output current

\section{1. まえがき}

整流回路とインバータを組み合わせた $\mathrm{AC}-\mathrm{AC}$ 間接変換 器に代わる小型・低損失の $\mathrm{AC}-\mathrm{AC}$ 直接変換器の実現を目 指して，マトリックスコンバータ (以下，MC という) (1)(2) が检討されている。一方, 近年, 電力変換器の入力高調波低 減に対する要求は厳しくなってきており，マトリックスコ ンバータを実用化する際にも，この入力高調波の低減策が 重要な検討課題の一つとなる。これまでに提案された MC の制御法による入力電流高調波低減は, $\mathrm{AC}-\mathrm{AC}$ 間接変換

\footnotetext{
* 東京工業大学大学院理工学研究科電気電子工学専攻

干 152-8552 東京都目黑区大岡山 2-12-1

Dept. of Electrical \& Electronic Eng., Tokyo Inst. of Tech.

2-12-1, O-okayama, Meguro-ku, Tokyo 152-8552

** 千葉大学工学部 電気機械工学科

干 263-8522 千葉市稲毛区弥生町 1-33

Dept. of Electronics \& Mechenical Eng., Chiba Univ.

1-33, Yayoi-cho, Inage-ku, Chiba-shi 263-8522
}

器において入力高調波低減策として用いる自励式整流回路 の場合と比較すると十分ではない。乥の主な理由として， $\mathrm{MC}$ は 1 段の変換器で電源側の制御と負荷側の制御を同時 に行っていることによる制約などが挙げられる。したがっ て，これらの制約を克服できる MC の入力電流波形改善法 を検討し，入力電流ひずみ率低減の可能性を追求すること は MC の実用化にあたって重要であると考えられる。

これまで提案された $\mathrm{MC}$ の制御法は，主回路の取り扱い の観点から 2 つに大別することができる。すなわち，MC を仮想的に整流回路とインバータが直流リンクを介して接 続されていると見なして制御法を考える仮想間接 $\mathrm{AC}-\mathrm{AC}$ 変換に基づく方式 ${ }^{(3)}$ (7) と, MC を実際の回路構成に即して 電源と負荷を直接接続する変換器として見なして制御法を 考える直接 $\mathrm{AC}-\mathrm{AC}$ 変換に基づく方式 ${ }^{(8) \sim(1)}$ に分類できる。 仮想間接 $\mathrm{AC}-\mathrm{AC}$ 変換に基づく方式では, 従来の電圧形 の間接 $\mathrm{AC}-\mathrm{AC}$ 変換器における自励式整流回路およびイン バータの制御法として実績のある制御法を適用できるメリッ 
トがある。例えば，電圧形の自励式整流回路とインバータ

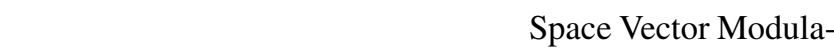
tion; SVM) を適用する間接空間ベクトル变調方式 (Indirect Space Vector Modulation; IDSVM) などが広く検討されて

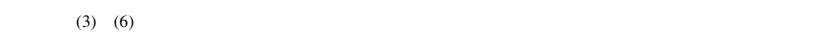
いる仮想間接 $\mathrm{AC}-\mathrm{AC}$ 変換方式の検討の報告もある(7)。し かし，一般に仮想間接 $\mathrm{AC}-\mathrm{AC}$ 変換に基づく制御法では， 仮想的に導入した整流回路とインバータの光れ光れに対し てスイッチングパターンを発生する操作が必要となる上， 実際の MC の主回路で実現するためには得られたスイッチ ングパターンに変換を施す必要があり，制御演算が複雑に なる傾向がある。また，仮想的に導入した整流回路とイン バータの制御の間に，実際には両者の主回路が共有されて いることに起因する $\mathrm{MC}$ 特有の干渉が生ずる点も考慮しな ければならない。

これに対して, MC を直接 $\mathrm{AC}-\mathrm{AC}$ 変換器として取り扱 う考え方に基づく制御方式の検討も進められている ${ }^{(8) \sim(1)}$ 。 直接変換に基づく制御法では, 従来の間接 $\mathrm{AC}-\mathrm{AC}$ 変換器 で用いられていた制御法を適用することはできないため， 新たな制御法を考案する必要がある。しかし，変換を 1 段 階で取り扱うため, スイッチングパターンの発生部分が簡 略化されるとともに，実際の MC の回路との対応が明確に なり概念的に理解しやすい点が特長であり，有用な方式の 一つと考えられる。また, 制御演算が簡便であるために,才 ンラインでスイッチングパターンを演算する際にも有利で ある。

筆者らはこれまで, 直接 $\mathrm{AC}-\mathrm{AC}$ 変換に基づく $\mathrm{MC}$ の制

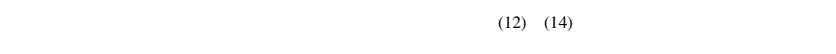
て, 電圧形インバータの PWM 制御に類似したキャリヤ比 較による PWM 制御を適用し，これに基づく出力電流瞬時 制御法を提案し, 入出力電流の波形改善効果について明ら かにした。これらの検討において，入力側 3 相のうち電圧 が中間の大きさを持つ相を負荷側に接続する割合 (以下 ,中 間相出力比) を調整することが , 入力電流の波形改善に大 きな影響を与えることを報告した。しかし，この方式では 中間相出力比と入力電流波形の相関力理論的に解明されて いないことと， 入出力電流波形ひずみに改善の余地が残さ れている問題があった。

一方，筆者らと同樣に MC の制御方式として PWM 制御 方式の適用を検討している文献 (9)〜(11) においても, 入力 側中間相の利用が入力電流の波形改善の面で重要であるこ とが指摘されている。さらに，この考え方に基づく入出力 電流波形改善法が提案され，実験により有効性の検討も行 われている。しかし，入力電流波形改善のために導入する 制御法に関して, 出力電流をパルス幅変調して入力電流波 形を合成する手順については明確に取扱われていない。現 状において，MC の制御法は確立途上の技術であるため， 制御法の導出の基礎となる考え方を明らかにすることは重 要であると考えられる。この観点から，理論的な裏づけを 提示しながら制御の手法を考察して導出することや，既に
提案されている種々の制御法との関係を明らかにすること は, 今後の研究への指針を与えるという点で意義深いこと である。

以上の背景を踏まえ，本論文では，筆者らか検討してきた PWM 方式をもとに, MCにおける入出力電流を理論的に 正弦波化するための PWM 方式の考え方を明らかにすると ともに，弚れに基づいて具体的な制御手法を導出する。ま ず, $\mathrm{MC}$ を出力側からは制御電圧源として動作する電圧形 変換器と見なし, 電源側からは制御電流源として動作する 電流形変換器と見なす考え方を提示する。次に，この考え 方に基づいて ,キャリヤ比較による PWM 制御と MC の制 御電圧源およひ制御電流源としての動作の関係を定式化し， 制御法を理論的に導出する。さらに，理論的に導出した制 御法を試作装置に適用し, 本論文における検討結果の妥当 性を明らかにする。最後に，本論文で提示した入出力電流 波形改善のための基本的考え方に立脚して，これまでに提 案されている $\mathrm{PWM}$ 制御に基づく MC の制御法の物理的意 味を考察し，弚の共通点を明らかにすることにより，制御 上の共通的指針を得る。

2. 入出力電流制御の考え方とスイッチングパター ン発生法

〈2. 1〉 入出力電流制御の基本的考え方 图 1 に示すよ うに,MCの主回路はLCフィルタを介して電源に接続され る。この LC フィルタは PWM 制御による周波数成分を除 去することが目的であるため, PWM スイッチング周波数 が通常数 $\mathrm{kHz}$ 以上に設定されることを考えると LCフィル タのLによる電源周波数における電圧降下の影響は小さい。 したがって，MCの出力側から見ると，電源電圧が MC の スイッチングにより切り出されたようになる。電源が電圧 源的であることを考えると，出力側から見た MC は PWM により制御される制御電圧源と見なすことができる。

一方，MCの負荷にモータなどが接続される場合を考え

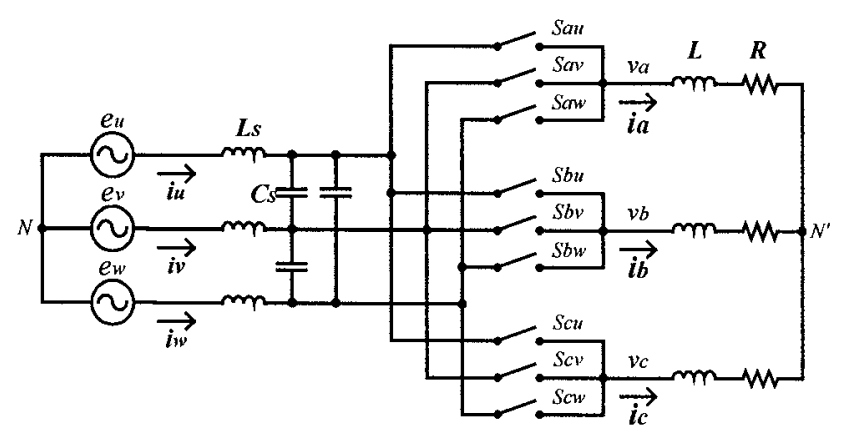

(a) Main circuit

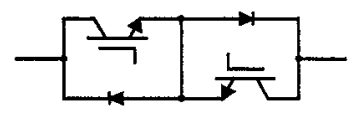

(b) Example of bi-directional switch

図 1 主回路構成

Fig. 1. Circuit configuration of matrix converter. 
ると,モータの漏れインダクタンス等の影響により，電流は 平滑化され PWM キャリヤ周期内では出力電流はほぼ一定 と見なすことができ，等価的に電流源として取り扱うこと ができる。電源側から MC を見た場合，出力電流を PWM 制御により電源側に切り出すように動作することになる。 したがって，電源側から見た MC は PWMにより制御され る制御電流源と見なすことができる。

以上のように, MCの PWM 制御は, 出力側に対する制 御電圧源としての動作と，電源側に対する制御電流源とし ての動作の双方を決定づけていることになる。したがって， 入出力電流の正弦波化を考えるには, 出力電流制御に必要 な制御電圧源としての機能を維持しつつ，MC を制御電圧 源として動作させる際の PWM 制御における自由度を利用 して電源側に正弦波状の電流を合成する制御電流源として 動作させるようにすればよいことになる。以下，本論文で は，この考え方に基づき，第 3 章で入力電流波形改善のた めに利用する PWM 制御上の自由度を確保しつつ出力電流 を制御する方法を検討し，これにもとづき，第 4 章でこの 自由度を利用して入力電流を正弦波化できる入力電流制御 法を検討する。

〈2. 2〉 スイッチングパターン発生法＼cjkstart本節では, 本論 文で検討する制御法の基礎となるこのスイッチングパター ン発生法を簡単に説明する。

图 1 に示す MC の基本回路構成を考える。入力側の 3 相 を $u, v, w$ 相, 出力側の 3 相を $a, b, c$ 相とする。図 1(a) 内 の $S_{a u} \sim S_{c w}$ は双方向スイッチであるが, 実際には图 1(b) に示したように2つのIGBT から構成されている。

図 2 に示すように入力側 3 相電圧の大小関係は，1 周期 に6回 (図 2中の期間 1-6 に対応) 変化する。例えば期間 1 では, 電圧が最大の相は $u$ 相 , 中間の相は $v$ 相 , 最小の相 は $w$ 相である。このような入力電圧の大小関係の把握は， $\mathrm{MC}$ を $\mathrm{PWM}$ 制御する際に重要である。以下 , 入力の相を 電圧の大小関係に応じて最大相, 中間相, 最小相と呼ぶ。光 の対応関係は図 2 に示したとおりである。

出力側 3 相については, 各相に対し 2 種類の指令值を用 いて PWM 制御を行う。すなわち, 出力 $x$ 相 $(x$ は任意の出 力相; $x=a \sim c)$ は指令値 $v_{x h}^{*}$ と指令値 $v_{x l}^{*}$ を用いて $\mathrm{PWM}$ 制御する。これらの指令值は，三角波キャリヤと併せて図 3 の上段に図示した。

次に，出力 $a$ 相を例に図 3 下段に示すスイッチングパター ンの発生法を説明すると，以下の通りとなる。なお，图 3 下段の max , mid, min は乥れ光れ入力側の最大電圧相 , 中 間電圧相 , 最小電圧相を表す。三角波キャリヤが $v_{a l}^{*}$ より小 さい期間は, 入力の最大相が出力 $a$ 相に接続される。例え ば , 図 3 に示す入力側が図 2 の期間 1 の場合 , 入力の最大 電圧相である $u$ 相が出力 $a$ 相に接続される $(\max =u$ 相 , ス イッチ $S_{a u}$ がオン)。三角波キャリヤが $v_{a h}^{*}$ と $v_{a l}^{*}$ の間にあ る期間は, 入力の中間相が出力 $a$ 相に接続される ( $m i d=v$ 相，スイッチ $S_{a v}$ がオン)。三角波キャリヤが $v_{a h}^{*}$ より大き い期間は, 入力の最小相が出力 $a$ 相に接続される $(\min =w$

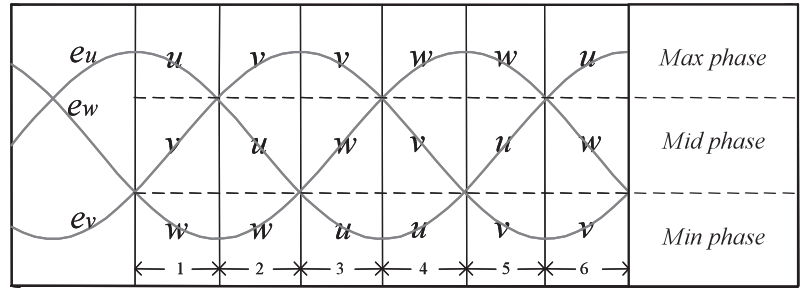

图 2 入力相電圧の大小関係

Fig. 2. Six cases determined by three-phase input voltage level.

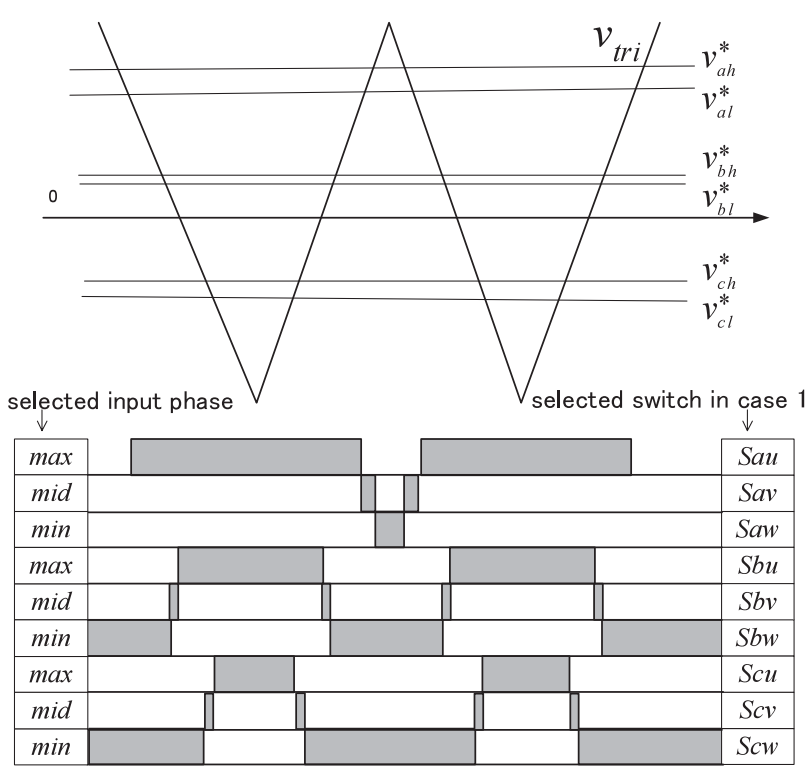

図 3 出力電圧 PWM 指令值と出力パターン例 (図 2 の期間 1 場合)

Fig. 3. Example of switching pattern (for period 1 in fig.2).

相，スイッチ $S_{a w}$ がオン)。以上のようにして , 入力 3 相 , 出力 3 相間の 9 個の双方向スイッチの導通状態を決定する。

3. 出力電流の正弦波化

〈3. 1〉 PWMによる出力電圧 $\mathrm{MC}$ の出力電流制御の 議論の準備のため, 電源に直流電圧源 $E_{D C}$ を持つ一般的な 三角波キャリヤ比較 PWM 方式の電圧形インバータの出力 電圧 PWM 指令值 $v_{x_{-} P W M}^{*}$ と, 実際に出力される電圧実値 の 1 キャリヤ周期内での平均值 $v_{x}$ の関係を考えると次式の ようになる。ここで, $x$ は任意の出力相 $(x=a \sim c)$ を意 味し， $A_{t r i}$ は三角波キャリヤの振幅である。

$$
v_{x}=\frac{v_{x-P W M}^{*}}{2 A_{t r i}} E_{D C} \quad(x=a \sim c)
$$

また, 見方を変えると, 出力電圧 PWM 指令值 $v_{x_{x} P W M}^{*}$ は, 出力電圧指令值 $v_{x}^{*}$ を三角波キャリヤの振幅 $A_{t r i}$ と直流 電圧源 $E_{D C}$ の比で規格化した值とも考えられる。

$$
v_{x_{-} P W M}^{*}=\frac{2 A_{t r i}}{E_{D C}} v_{x}^{*}
$$


一般に $v_{x}^{*}$ および $v_{x \_P W M}^{*}$ の関係を明確にするため，ここ で $v_{x}$ を含めて制御系の流れに沿って整理すると次のように なる。

まず，電流制御系やモ一タ制御系などからの指令值によっ て, 出力電圧指令值 $v_{x}^{*}$ が与えられる。次に, $v_{x}^{*}$ は (2) 式に よって直流電圧源 $E_{D C}$ で規格化され， $v_{x_{-} P W M}^{*}$ に変換され る。最後に $v_{x P W M}^{*}$ は PWM 制御器へ与えられ, 負荷の $x$ 相に実際の電圧の 1 キャリヤ内の平均値 $v_{x}$ が出力される。 制御が正確に行なわれているならば， $v_{x}$ の值は $v_{x}^{*}$ と等しく なる。

次に (1) 式を $\mathrm{MC}$ に拡張する。 $\mathrm{MC}$ において, 電圧形イ ンバータの直流側電圧に相当するものは電源の線間電圧で あるため, 入力側の 2 つの線間電圧を用い, 次式のような 2 つの等価電圧源を考える。

$$
\begin{aligned}
& e_{l-l, \text { max }}=(\text { 最大相電圧 }- \text { 最小相電圧 }) \\
& e_{l-l, \text { mid }}=(\text { 中間相電圧 }- \text { 最小相電圧 })
\end{aligned}
$$

图 4 に $e_{l-l, m a x}, e_{l-l, \text { mid }}$ の波形を示す。電圧形インバータの 直流電源と異なり，入力線間電圧は图 4 のように脈動する。

前章の図 3 で示した PWM パターンを用いると, 出力電 圧の実值の 1 キャリヤ周期における平均值 $v_{x}$ と電圧指令值 の関係は次式となる。

$$
v_{x}=\frac{v_{x l}^{*}}{2 A_{t r i}} e_{l-l, \text { max }}+\frac{v_{x h}^{*}-v_{x l}^{*}}{2 A_{t r i}} e_{l-l, \text { mid }}
$$

ここで,(5) 式の第 2 項 $e_{l-l, m i d}$ の係数 $v_{x h}^{*}-v_{x l}^{*}$ は, 図 3 から 分かるとおり入力の中間相が出力 $x$ 相に接続されるデュー ティとなっている。乥こでこれを中間相出力比 $k_{x}$ と表記 し，次式のように定義する。

$$
k_{x}=v_{x h}^{*}-v_{x l}^{*}
$$

出力される電圧実値 $v_{x}$ (1 キャリヤ周期内の平均値) の 值を $v_{x}^{*}$ と等しくすることを考え，(5) 式の $v_{x}$ を $v_{x}^{*}$ に置換 $し,(6)$ 式の関係を用いると, 出力 $x$ 相の PWM 指令值 $v_{x h}^{*}$, $v_{x l}^{*}$ は次式のようになる。

$$
\begin{aligned}
& v_{x h}^{*}=\frac{2 A_{t r i}}{e_{l-l, \text { max }}} v_{x}^{*}+k_{x}\left(1-\frac{e_{l-l, \text { mid }}}{e_{l-l, \text { max }}}\right) . \\
& v_{x l}^{*}=\frac{2 A_{t r i}}{e_{l-l, \text { max }}} v_{x}^{*}-k_{x}\left(\frac{e_{l-l, \text { mid }}}{e_{l-l, \text { max }}}\right) \ldots \ldots
\end{aligned}
$$

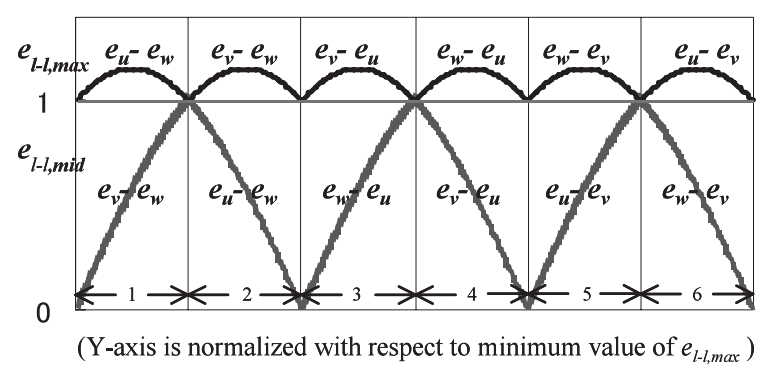

图 4 入力電圧の等価電圧源としての取り扱い

Fig. 4. Input line-to-line voltage.
(7) 式および (8) 式により，中間相出力比 $k_{x}$ と制御系の出 力電圧指令值 $v_{x}^{*}$ を独立に設定することが可能となる。すな わち, $v_{x}$ を出力電流制御で要求される值に制御し, かつ, 中 間相出力比 $k_{x}$ を自由な変数として使用できることになる。

〈3. 2〉 入力電圧脈動の補償制御 $\mathrm{MC}$ の出力電圧制御 に用いる 2 つの入力線間電压 $e_{l-l, \text { max }}, e_{l-l, \text { mid }}$ は図 4 のよう に脈動するため, 電圧形インバータと同樣な電圧指令值の (1) 式を用いる場合, 出力電圧指令值 $v_{x}^{*}$ が正弦波であって も実際の出力電圧 $v_{x}$ は正弦波にならず，ひずんだ波形に なる。

ここで, 電圧指令值を操作することにより入力電圧脈動を 補償する方法を考える。まず, MCが入力電圧の位相にかか わらず必ず出力できる最大電圧は入力線間電圧振幅の $\sqrt{3} / 2$ 倍で, 图 4 線間電圧 $e_{l-l, \text { max }}$ の瞬時値の最小値 $\min \left(e_{l-l, \max }\right)$ である。

(2) 式の $E_{D C}$ の代わりに $e_{l-l, \text { max }}$ の最小値 $\min \left(e_{l-l, \text { max }}\right)$ を 用い, MC の制御系内の PWM 電圧指令值 $v_{x_{-} P W M}^{*}$ を表わ すと次式のようになる。

$$
v_{x_{P} P W M}^{*}=\frac{2 A_{t r i}}{\min \left(e_{l-l, \max }\right)} v_{x}^{*} \text {. }
$$

この (9) 式に対して $e_{l-l, \text { max }}$ の脈動を補償するため, $\min \left(e_{l-l, \max }\right) / e_{l-l, \max }$ を用いて新たに規格化を行う。さらに， (7) と (8) 式を用いて 2 つ PWM 指令值 $v_{x h}^{*}, v_{x l}^{*}$ を求める と次式になる。

$$
\begin{array}{r}
v_{x h}^{*}=\frac{\min \left(e_{l-l, \max }\right)}{e_{l-l, \max }} v_{x-P W M}^{*}+k_{x}\left(1-\frac{e_{l-l, \operatorname{mid}}}{e_{l-l, \max }}\right) \ldots . \\
\ldots \ldots \ldots \ldots \ldots \ldots \\
v_{x l}^{*}=\frac{\min \left(e_{l-l, \max }\right)}{e_{l-l, \max }} v_{x \_P W M}^{*}-k_{x}\left(\frac{e_{l-l, \operatorname{mid}}}{e_{l-l, \max }}\right) \ldots \ldots \ldots
\end{array}
$$

本方式では, 上式の $v_{x_{-} P W M}^{*}$ は出力電流の PI 制御 器から出力される指令值であり, 右辺第 1 項の係数 $\min \left(e_{l-l, \max }\right) / e_{l-l, \text { max }}$ によって線間電圧 $e_{l-l, \text { max }}$ の脈動を補 償する形になっている (制御系の構成は図 9 を参照)。以上 の方法により，出力電圧を指令値通りに制御しつつ，中間 相出力比 $k_{x}$ を自由に設定できるとともに, 出力電圧指令値 の補正により電源電圧の脈動分の補償も実現し, 結果とし て出力電流を指令值どおりに制御することが可能となる。

\section{4. 入力電流の正弦波化}

本章では，〈2・1〉節で述べたように，MC を電源側から みた場合, 出力側の三相電流を PWM によって電源に切り 出す制御電流源として考え, 第 3 章で導入した中間相出力 比 $k_{x}$ の自由度を利用し，入力電流を正弦波化する方法を説 明する。

以降の説明では, $\mathrm{MC}$ 各部を流れる電流の名称を図 5 の ように定義して用いる。なお，図 5 は入力電圧の各相の大 小関係が図 2 の期間 1 の場合を例に描いた。図 5 の $i_{\text {max }}$ ， $i_{\text {mid_i }}, i_{\text {min_i }}$ は光れ艺れ電源側の最大相, 中間相，最小相に おける MC の電源側電流である。图 5 に示した図 2 の期 


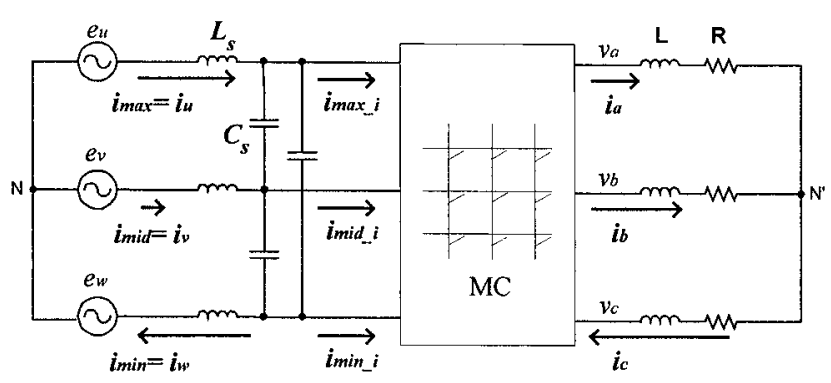

図 5 MC 入出力各部の電流の定義（図 2 の期間 1 場合)

Fig. 5. Definition of currents in input and output sides of MC (for period 1 in fig. 2 ).

間 1 では, $i_{\text {max } \_i}=i_{u}, i_{\text {mid_i }}=i_{v}, i_{\text {min_i }}=i_{w}$ である。電源 側電流 $i_{\text {max_i }}, i_{\text {mid_i }}, i_{\text {min_i }}$ はパルス状であり，負荷電流を PWM 制御した結果，合成される。図 3 のスイッチングパ ターン発生法を用いた場合の入力電流を, 出力電流を用い て表すと次の式になる。ただし，ここでも 3 章の出力電圧 の式と同樣に 1 キャリヤ周期あたりの平均值で考えること にする。

$$
\begin{aligned}
& i_{\text {max } \_i}=\frac{v_{a l}^{*}+A_{t r i}}{2 A_{t r i}} i_{a}+\frac{v_{b l}^{*}+A_{t r i}}{2 A_{t r i}} i_{b}+\frac{v_{c l}^{*}+A_{t r i}}{2 A_{t r i}} i_{c} \\
& i_{\text {mid } \_i}=\frac{k_{a}}{2 A_{t r i}} i_{a}+\frac{k_{b}}{2 A_{t r i}} i_{b}+\frac{k_{c}}{2 A_{t r i}} i_{c} \ldots \ldots \ldots \ldots \ldots \ldots \ldots \ldots \\
& i_{\text {min } \_i}=\frac{A_{t r i}-v_{a h}^{*}}{2 A_{t r i}} i_{a}+\frac{A_{t r i}-v_{b h}^{*}}{2 A_{t r i}} i_{b}+\frac{A_{t r i}-v_{c h}^{*}}{2 A_{t r i}} i_{c}
\end{aligned}
$$

図 6 は, 中間相出力比 $k_{x}$ と入力電流波形の関係を説明し たものである。図 6(a) は中間相出力比 $k_{a}, k_{b}, k_{c}$ を 0 とし た時の入力 $v$ 相電流波形例である。中間相出力比が全て 0 のため, 入力の中間相は 1 キャリヤ周期の間を通じて , 出 力側に全く接続されない。例えば, $v$ 相が中間相となる期間 (图 2 の期間 1 および 4 ) では, $v$ 相の電源側電流（図 5 の $i_{\text {mid_i }}$ に相当) が全く流れない。光の結果， $v$ 相の MC の電 源側の電流 $i_{v}$ は，低次のひずみを多く含んだ波形になる。

ここで, $v$ 相が中間相となる期間で, $k_{a}, k_{b}, k_{c}$ を操作し て $v$ 相の電源側電流を制御する。また,$v$ 相が最大相や最 小相の期間では他の $u$ 相や $w$ 相が中間相になり，同樣の考 え方で中間相出力比を調整する。すなわち $, k_{a}, k_{b}, k_{c}$ を操 作して入力側中間相に流れる電流 $i_{\text {mid }}$ が図 6(c) の $i_{\text {mid }}^{*}$ のよ うに，基本波力率が 1 となる三相正弦波波形の一部となる 波形に一致するように制御する。ここでは，入力中間相の 電流のみを基本波力率 1 の正弦波入力電流の一部となるよ う制御し, 入力最大相，最小相の電流波形は直接的には制 御しないが, 出力電流が三相平衡である場合, 式 (12) およ び(14)より，最大相，最小相の入力電流も基本波力率 1 の 正弦波入力電流の一部となることか理論的に示される ${ }^{(15)}$ 。 したがって，以下て説明する方法で中間相の入力電流波形 を制御すれば，結果として入力電流が基本波力率 1 の三相

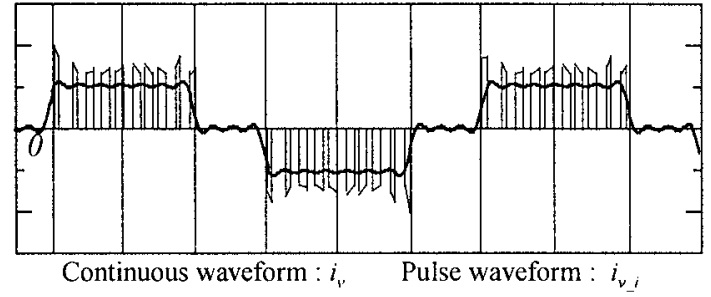

(a) Middle phase duty $k_{x}$ is 0

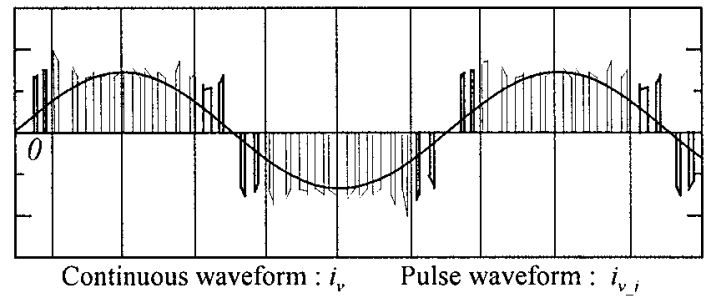

(b) Middle phase duty $k_{x}$ is appropriate

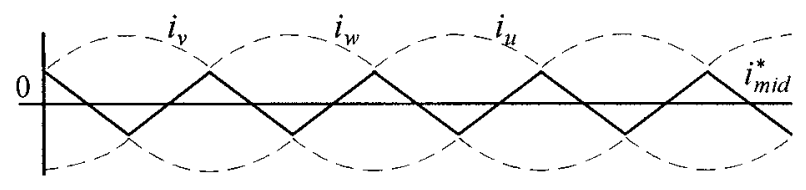

(c) Reference current waveform of middle phase

図 6 中間相出力比 $k_{x}$ と入力電流波形の関係

Fig. 6. Relation of middle phase duty $k_{x}$ and input current waveform.

平衡正弦波となる。

次に，(13) 式左辺の $i_{\text {mid_i } i}$ の值が図 6(c) に示すように入 力電流を正弦波化するための中間相電流指令值 $i_{\text {mid }}^{*}$ と一致 するような， $k_{a}, k_{b}, k_{c}$ の決定法について述べる。

1 つの式である (13) 式から，独立な 3 つの変数 $k_{a}, k_{b}$, $k_{c}$ を決定するため，以下の 2 つの制御則を導入する。

まず，入力中間相の入力電流を制御する際には，負荷側 各相の電流のうち, 兴の符号が中間相電流指令值の符号と 一致する出力相の電流のみを用いて制御を行う。すなわち， 出力 $x$ 相の電流 $i_{x}$ が中間相電流の指令值 $i_{\text {mid }}^{*}$ と反対方向 (異符号) なら, デューティ $k_{x}$ は 0 とし, 弚の出力相の電 流は入力中間相には流さない。次に, 出力 $x$ 相の電流 $i_{x}$ が 中間相電流の指令值 $i_{m i d}^{*}$ と同方向 (同符号) なら, デュー ティ $k_{x}$ は正の值とする。複数の出力相電流の符号が $i_{\text {mid }}^{*}$ の 符号と一致する場合は弚の 2 相の $k_{x}$ を等しい值にする。

例えば, $i_{\text {mid }}^{*}>0, i_{a}>0, i_{b}>0, i_{c}<0$ の場合, $k_{a}=k_{b}>0$, $k_{c}=0$ にする。この 2 つ制御則は, 图 7 のように , 大き さ $+i_{\text {sum }},-i_{\text {sum }}$ の等価電流源のうち符号の一致する一方を 用いて， $i_{\text {mid }}$ を合成することと等価である。ただし $i_{\text {sum }}$ は 次式で表される。

$$
i_{\text {sum }}=\operatorname{sgn}\left(i_{a}\right) i_{a}+\operatorname{sgn}\left(i_{b}\right) i_{b}+\operatorname{sgn}\left(i_{c}\right) i_{c}
$$

ここで関数 $\operatorname{sgn}$ は，引数の符号が正なら 1 を，引数の符 号が負なら 0 と定義する。この等価電流源 $+i_{\text {sum }},-i_{\text {sum }}$ の 值は図 8 のように周期的に変化する。

以上の考え方をまとめると, 出力 $x$ 相の中間相出力比 $k_{x}$ 
は次式で与えられる。

$$
k_{x}=2 A_{\text {tri }} \frac{i_{\text {mid }}^{*}}{i_{\text {sum }}}
$$

ただし， $i_{x}$ が $i_{m i d}^{*}$ と異符号の出力 $x$ 相では $k_{x}=0$ にし, 出力電流が $i_{m i d}^{*}$ と同符号の出力相の電流のみを入力電流制 御に用いる。

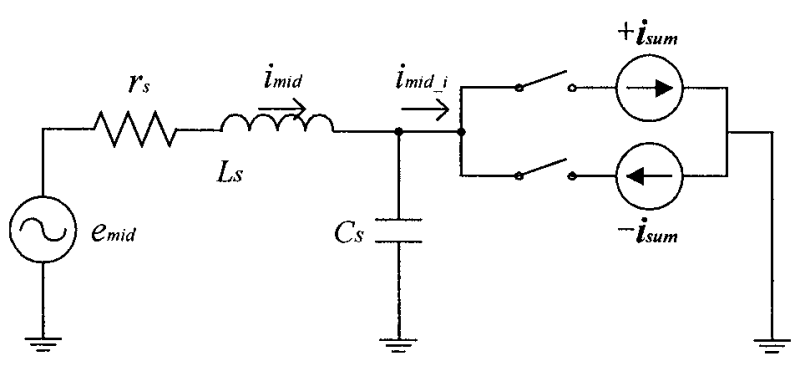

図 7 MC 入力中間相の電源側単相等価回路

Fig. 7. Single phase equivalent circuit of middle phase in line side.

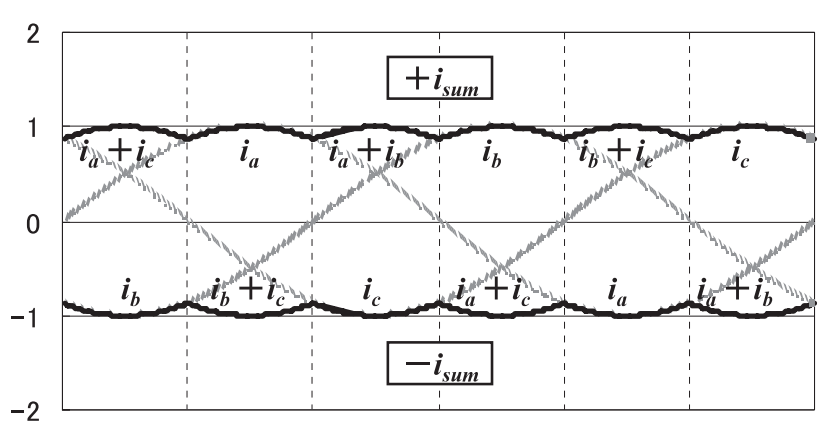

(Y-axis is normalized with respect to maximum value of $i_{\text {sum }}$ )

图 8 等価電流源 $+i_{\text {sum }},-i_{\text {sum }}$

Fig. 8. Equivalent current source $+i_{\text {sum }}$ and $-i_{\text {sum }}$.

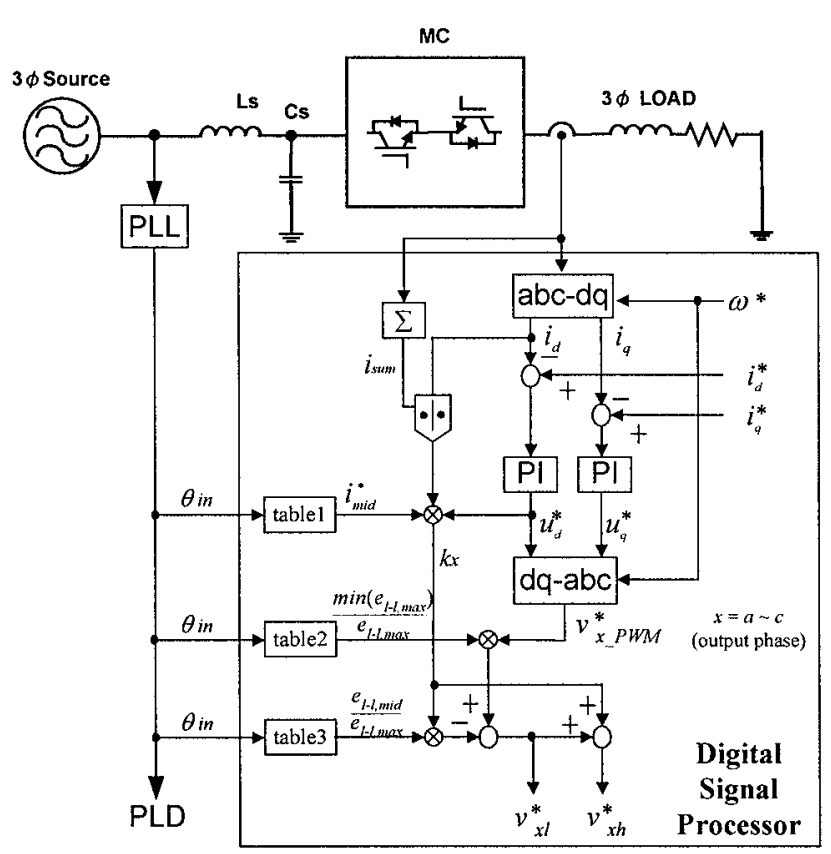

図 9 制御ブロック図

Fig. 9. Control block diagram.
次に , 中間相出力比 $k_{x}$ を求めるための (16) 式の演算を 実現する方法を具体的に説明する。MC の入力力率を 1 に 制御することを考えると， $i_{m i d}^{*}$ の波形は入力電圧と同相の 三相正弦波電流波形の一部となるようにすればよい。この $i_{m i d}^{*}$ の波形は以下の手順で求められる。まず，MC の損失 を無視し, 入力側の有効電力と出力側の有効電力は等しい と仮定して, 検出した出力電流と制御系内の出力電圧指令 値から入力電流の振幅を計算する。次に, 入力電源電圧の 位相情報を用いて図 6(c) に示した中間相電流指令值 $i_{\text {mid }}^{*}$ の 位相を決定する。また， $i_{\text {sum }}$ は，(15) 式のように出力相の 電流検出値のうち, $i_{\text {mid }}^{*}$ と同符号を持つ相の和で決定され る。以上で述べた指令值を演算する制御系をブロック图で 示すと図 9 のようになる。

\section{5. 実験結果の考察および PWM 方式の比較検討}

〈 5 1〉 シミュレーションおよび実験以降ではシミュ レーション及び実験により，図 9 に示した本論文で検討す る制御方式による入出力電流波形を検証する。この制御系 は AC ドライブ用インバータ等で広く用いられている dq 軸 上でPI 制御を行う電流制御系を基本とし，本論文で検討 する MC としての制御系を付加した構成になっている。シ ミュレーションおよび実験の条件は表 1 に示す。

まず，入力電流力理論通り，正弦波状に制御できること を確認するためのシミュレーションを行った。図 10 の (a) から (c) の波形は 4 章の (12) 式から (14) 式の 3 つの計算值 を示している。これらの値は出力電流の検出値と制御系内 の $v_{x h}^{*}, v_{x l}^{*}$ から算出した演算値で, LCフィルタと MC の間 を流れるパルス状電流を 1 キャリヤ周期ごとに平均した值

表 1 実験定数

Table 1. Parameters.

\begin{tabular}{l|c|c}
\hline \multirow{2}{*}{ Power source } & Line-to-line Voltage & $50[\mathrm{~V}]$ \\
\cline { 2 - 3 } & Frequency & $50[\mathrm{~Hz}]$ \\
\hline $\begin{array}{l}\text { Input filter } \\
\text { Inductor } \\
\text { (Per phase) }\end{array}$ & Inductance $L$ & $1[\mathrm{mH}]$ \\
\cline { 2 - 3 } & Resistance $R$ & $(2.5 \%)$ \\
\hline Input filter & Capacitance $C$ & $0.2[\Omega]$ \\
Capacitor & ( $\Delta$ Connection) & $4.8[\mu \mathrm{F}]$ \\
\hline
\end{tabular}

Parameters in simulation

\begin{tabular}{l|c|c}
\hline & Output current & $7[\mathrm{~A}]$ \\
\hline \multirow{2}{*}{$\begin{array}{l}\text { Load } \\
\text { (Per phase) }\end{array}$} & $L_{\text {Load }}$ & $5[\mathrm{mH}]$ \\
\cline { 2 - 3 } & $R_{\text {Load }}$ & $1[\Omega]$ \\
\hline \multicolumn{3}{|c}{ Parameters in experiment } \\
\hline \multicolumn{3}{|c}{ Output current } \\
\hline \multirow{2}{*}{$\begin{array}{l}\text { Load } \\
\text { (Per phase) }\end{array}$} & $L_{\text {Load }}$ & $2[\mathrm{~A}]$ \\
\cline { 2 - 3 } & $R_{\text {Load }}$ & $5[\mathrm{mH}]$ \\
\hline
\end{tabular}




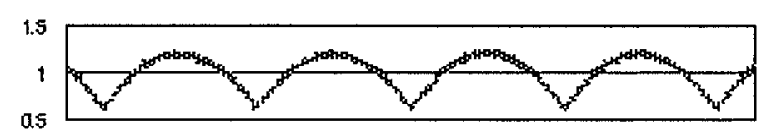

(a) Average value of $i_{\text {max } \_}$.

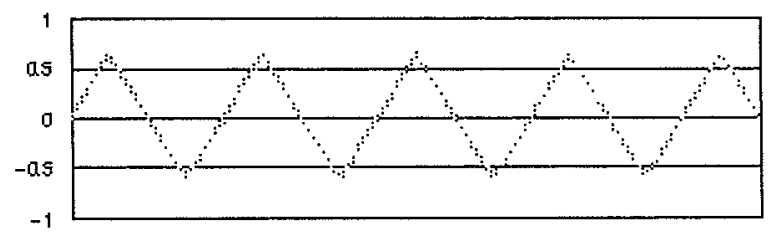

(b) Average value of $i_{\text {mid } \_}$.

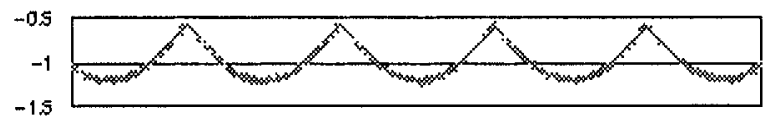

(c) Average value of $i_{\text {min_i } i}$.

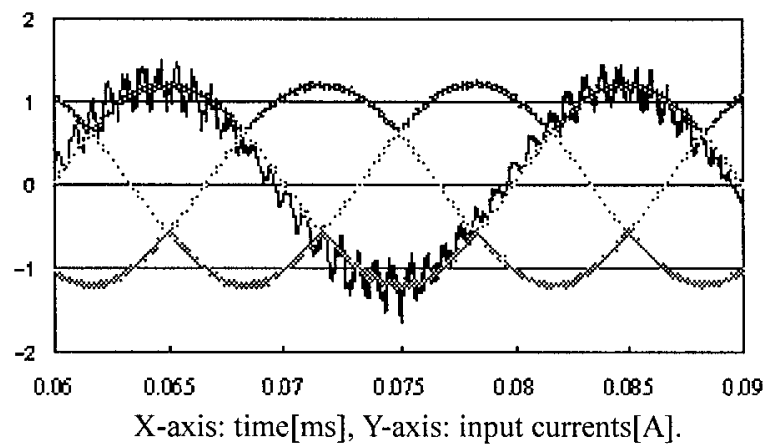

(d) Input current of phase-u and average values.

図 10 入力電流の合成 (シミュレーション結果)

Fig. 10. Synthesized input current waveforms (simulation result).

に相当する。これらに入力 $u$ 相の電流波形 $i_{u}$ と，(12) 式か ら (14) 式の 3 つの計算値を併せて図 10(d) に示す。 $i_{\text {max_i }}$,

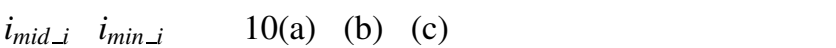
算しているが , (d) に示すようにこれらを合わせると同一の 三相平衡正弦波電流となる。また，これらを合わせた正弦 波状電流演算值と実際の電源電流 ( $u$ 相の $i_{u}$ のみ表示) は 一致していることがわかり，検討した方式により入力電流 の正弦波化か実現されていることが確認できる。

次に，試作装置により実験を行った結果を示す。試作装 置のシステム構成図を図 11 に示す。本論文で検討する制 御方式の入出力電流波形改善効果を確認するため，2 つの 条件で比較検討を行った。まず, 方式 A では入力電圧の脈 動の補償を行わない条件で中間相出力比のみを制御した場 合である。すなわち，3 章の式 (7)，(8) と4 章の (16) 式を 用いて制御した。この方式 $\mathrm{A}$ は筆者らか旣に提案した方式 に準じている ${ }^{(13)}$ 。一方, 方式 B では入力電圧脈動を考慮し ながら中間相出力比制御を用いた場合である。すなわち， (10) と（11）式を求め，最後に (16) 式を用いた場合であり， 本論文で述べた全ての制御を行った場合である。

これらの方式 A および B について，実験による入出力 の電圧・電流波形を図 12 に示す。同図 (a) および (b) は， 上から順に入力線間電圧, 出力線間電圧, 入力電流, 出力

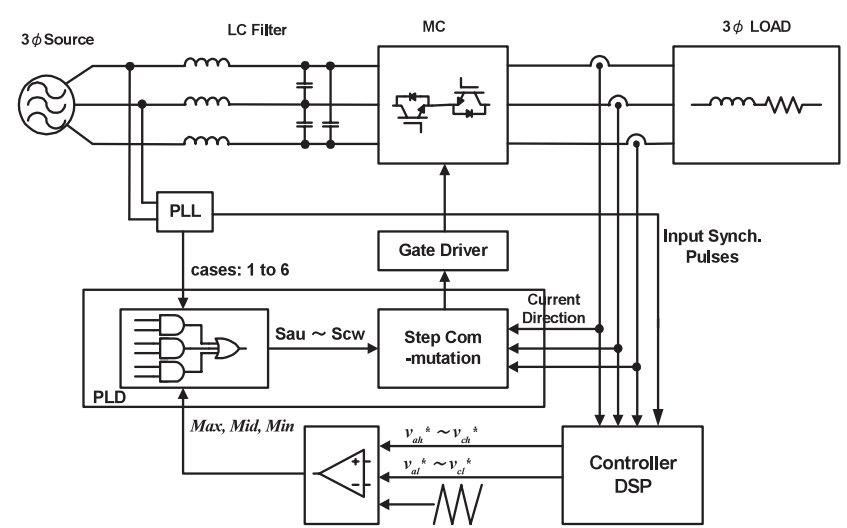

図 11 システム構成図

Fig. 11. System configuration.

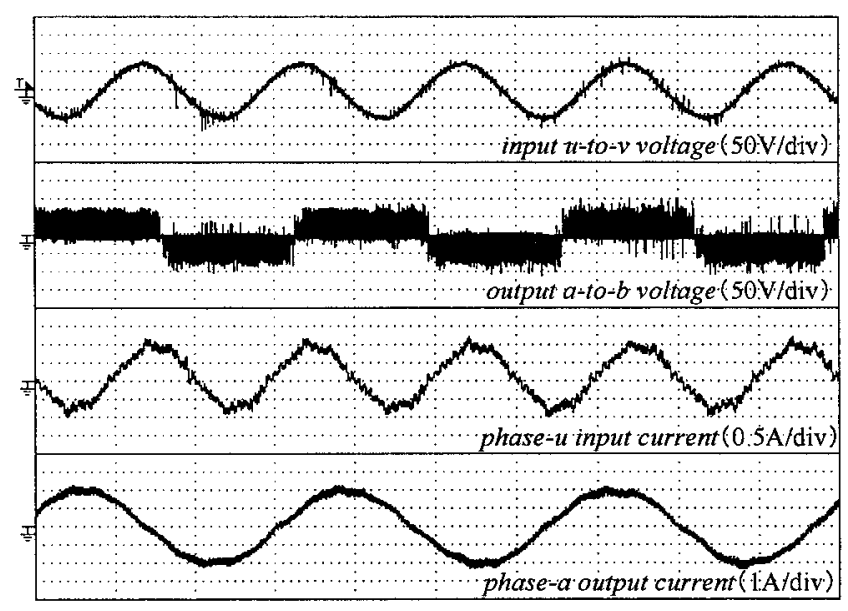

Time scale is $10 \mathrm{msec} / \mathrm{div}$

(a) Method A.

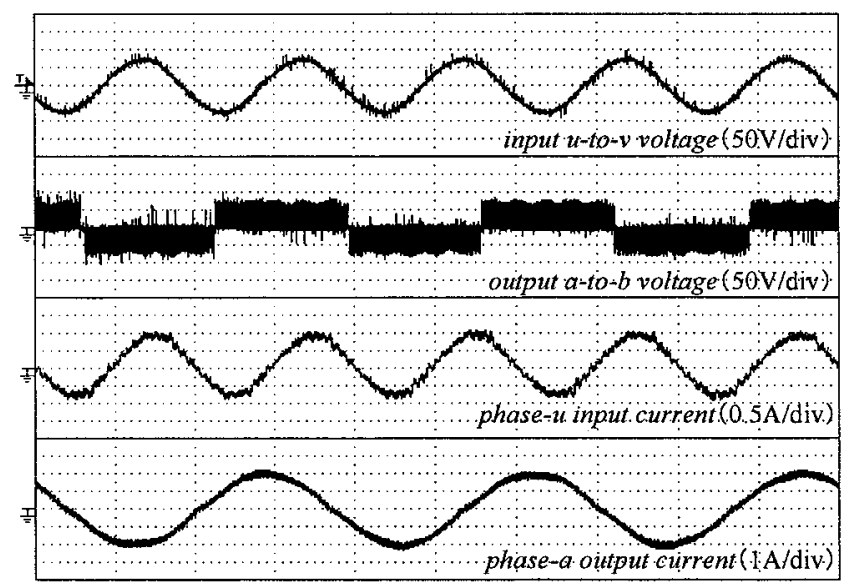

Time scale is $10 \mathrm{msec} / \mathrm{div}$

(b) Method B.

図 12 入出力電圧・電流の実験波形

Fig. 12. Voltage and current waveforms in input/output side (experimental result).

電流を示している。方式 A の結果である図 12(a) では，入 力電流 $i_{\text {mid }}$ のみが正弦波状に制御されている。しかし，他 の $i_{\text {max }}$ と $i_{\text {min }}$ に相当する入力電流の正負のピーク付近が ずんでいる。これに対して，方式 Bでは，理論通りに入力 
電流および出力電流の双方が正弦波になっている。すなわ ち, 入力電圧脈動の考慮により出力電流の波形も同時に改 善され，㚇の結果として入力電流の波形も改善しているこ とが分かる。

さらに, 図 13 に入力電流の周波数解析結果の一例として 变調比 54 [\%] の場合の結果を示す。図 13(a) は出力周波数 が $30 \mathrm{~Hz}$,(b) は $50 \mathrm{~Hz}$ の結果であり, 前述の制御方式 A , B の結果を同時に示した。出力周波数の変化による入力電流 THD の大きな変化はみられず, 商用電源周波数 $(50 \mathrm{~Hz})$ と 出力周波数が一致した (b) ではひずみ率がやや高い数值を 示した。入力電流の THD (20 次まて計算) は方式 A の場合 9.01 [\%] と 10.77 [\%] で，方式 B では 3.82 [\%] と 4.58 [\%] であり，方式 B における入力電流の THD の改善が確認さ れた。また，方式 A で目立っていた低次の高調波成分が方 式 Bでは効果的に抑えられている。

〈5 2〉実験結果の考察 以上の実験結果をまとめると， $\mathrm{MC}$ の中間相出力比を操作することによる入力電流波形の 改善効果は有効であり，本論文で検討した入力電圧脈動お よび出力電流波形の補償を併用することにより，入出力電 流の正弦波化が両立できることを示した。さらに , 図 12 の (a) と (b) の電流波形を比較すると，(b) は (a) に対し，入出 力電流の双方が同時に改善されている点は大变興味深い。

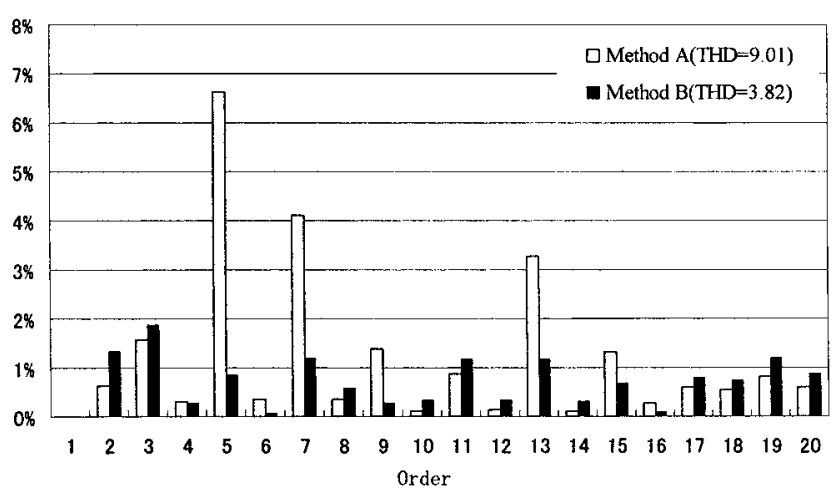

(a) Harmonics of input current

(output frequency: $30 \mathrm{~Hz}$ ).

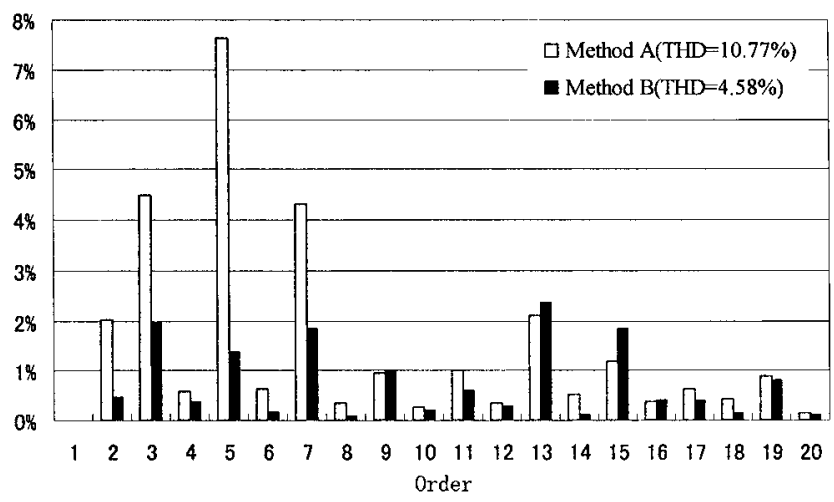

(b) Harmonics of input current

(output frequency: $50 \mathrm{~Hz}$ ).

図 13 入力電流周波数解析結果

Fig. 13. Harmonics of input current (experimental result).
一般に三相平衡回路の瞬時電力には脈動が存在しない。 従って，エネルギ一蓄積要素を持たない MC の場合でも，入 出力の電流を同時に三相平衡正弦波にすることは原理的に 可能であることは明らかである。これに対し，入出力電流 のいずれが一方にひずみが生じたとすると，瞬時電力の平衡 条件から他方の電流にも必然的にひずみを生ずることとな る。入出力電流の双方にひずみを生じている状況が図 12(a) の結果である。これに対し，入出力の瞬時電力平衡状態を 維持しつつ, 入出力電流の双方が正弦波化されている状況 が図 12(b)であると考えられる。したがって，本論文で検 討した制御法は, 入出力電流が同時に正弦波化されている 図 12(b) の状態を実現できており，MC の入出力電流制御 における原理的到達点を実現したものと言える。

〈5.3〉 MCにおける PWM 方式の比較検討 本論文 で検討したような PWM 方式に基づく $\mathrm{MC}$ の入出力電流の 正弦波化については，これまでにもいくつか報告例(8) (11) が ある。これらにおいても，入力電流波形を悪化させない観 点から，線間電圧が最大となる組み合わせの 2 相だけでな く，電源の中間電圧相を用いて出力制御をする必要性か指 摘されている。この中間電圧相を利用する時間的比率を表

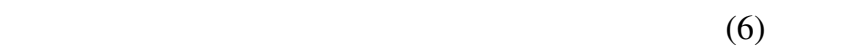
定義した変数 $k_{x}$ に相当する中間電圧相の出力時間比率を表 す変数を導入している。さらに, 中間電圧相を用いても出 力制御に必要な電圧指令值に対応した出力電圧が実現でき るように，中間電圧相の利用を前提としたパルス幅の決定 法を提案している。また，この際に，入力電圧の瞬時值が 電源周波数て脈動するため，この脈動を補償して制御を行 うことも考慮されている。文献 (10)では, 弚の具体的な方 法として，PWM 制御に用いるキャリヤ信号の振幅を変化 させ，電源電圧の脈動の影響を相殺するような手法を提案 している。本論文では, 電源電圧の瞬時値を基準値で規格 化し，この值でPWM 制御の指令值を除すことにより，電 源電圧の脈動の影響を相殺している。文献 (10) と本論文で は，具体的な実現法は異なっているが，物理的には等価な 操作を行っていることか理解できる。

一方 , 入力電流波形を改善するためには, 前述の中間電 圧相の出力時間比率 $k_{x}$ に相当するパラメータをどのように 決定するかがポイントとなる。第 4 章で説明したように， 本論文の方式は, 入力側から MC を見た場合には電流形電 力変換器と見なせることに立脚し, 出力各相電流のうち電 流の方向が一致する相の出力電流を用いて, 入力中間電圧 相の電流を PWM により合成するという考え方に基ついて 制御法を導出している。さらに, 入力中間電圧相の電流を 正弦波状に制御すれば，結果として他の 2 相の入力電流も 正弦波状となることを理論的に示し ${ }^{(15)}$ ，検討した入力電流 波形改善法の妥当性を理論的に明らかにしている。このと き, 入力中間電圧相の電流指令值を入力相電圧と同相にす ることにより，入力基本波力率を 1 に保つことができる。

これに対し，文献(10)(11)では，入力の最大電圧相と中 間電圧相の相電圧の比率を求め, この比率で出力電流を入 
力の最大電圧相と中間電圧相に振り分ける方法を用いてい る。これにより，入力相電流は入力相電圧の瞬時值に対す る比例関係を保ったまま制御され，結果として入力電流波 形は入力電圧波形と相似となり，入力基本波力率は 1 に制 御されることがわかる。同樣に，入力基本波力率を 1 に制 御する目的から , 入力各相の電流を入力相電圧と時間的に 相似な波形にするために, 入力各相の出力時間比率を入力 相電圧と比例させるという基本的な考え方は, 文献(8)に おいても示されている。以上の観点から, 文献(10)(11)の 方式と本論文で導出した方式では, 入力電流制御法のアプ ローチは異なっているが, 発生する PWM パターンの出力 順序などの詳細を別にすれば，結果として行っている操作 は等価であることがわかる。また , 文献(10)(11)の方式で は, 入力電流指令值の值兴のものを用いず，最大電圧相と 中間電圧相の入力電圧の比のみを用いているため, 本論文 の方式のような入出力間の電力の平衡条件を持ち出すこと なく，簡便に制御系を構成できる。

以上のように,本論文で検討した制御法を導出する過程で 議論した基本的考え方によれば,従来提案されていた PWM 方式に基づく MC の入出力電流改善法の物理的意味につい ても共通に説明できることが明らかとなり，本論文で議論 したアプローチが入出力電流波形改善の共通的指針として 妥当であることが示された。

なお，本稿では直接変換方式に基づく制御法に絞って検 討を行ったが，MCを等価的に整流回路部とインバータ部 に分けて考え，これら両者に対するスイッチングパターン を論理合成してスイッチングを決定する仮想間接変換方式 についても多数の検討例が報告されている。これらの仮想 間接変換方式の場合においても，最終的な結果として得ら れる各双方向スイッチのスイッチング信号は直接変換のも のと概ね類似のものとなる。したがって，仮想間接変換方 式の制御法についても，本章で述べたような物理的な意味 ブけが可能であると考えられる。

\section{6. むすび}

本論文では，正弦波入出力電流を実現するための PWM 制御に基づく MC の制御法における考え方を示し，この考 え方に基づいて具体的な制御法を導出した。具体的には， $\mathrm{MC}$ が電源側に対しては制御電流源として, 出力側に対し ては制御電圧源として動作していることに着目し，制御電 圧源および制御電流源としての振る舞いと PWM 指令值の 関係を定式化し，これに基づいて理論的に制御法を導出し た。乥の際，出力電流制御に 2 種類の入力線間電圧を用い， 弚の出力比率を調整することで出力電流の制御性を維持し つつ, 入力電流の波形改善が実現された。さらに, 入力電 圧および出力電流の脈動の影響を補償する制御を組み込む ことで, 入出力電流が同時に正弦波化される MC の入出力 電流制御における理想的な状況か実現されることか理論的 および実験的に確認された。

最後に,本論文での議論のアプローチに立脚して, 従来提
案されてきた PWM 方式に基づく制御法の比較検討を行っ た。兴の結果, 本論文のアプローチが, 各方式に共通する 基本的な考え方となっていることを指摘し，入出力電流波 形改善のための指針を明らかにした。

(平成 15 年 5 月 28 日受付, 平成 16 年 6 月 2 日再受付)

\section{文献}

(1) M. Venturini: "A new sine wave in, sine wave out, conversion technique eliminates reactive elements", Proc. POWERCON 7, pp. E3:1-E3:15 (1980)

( 2 ) P.W. Wheeler, J. Rodriguez, J.C. Clare, L. Empringham, and A. Weinstein: "Matrix converters: A technology review", IEEE Trans. Ind. Electron., Vol.49, No.2, pp.276-288 (2002-2)

( 3 ) C. Klumpner, P. Nielsen, I. Boldea, and F. Blaabjerg: "A new matrix converter-motor (MCM) for industry applications", IEEE Trans. Ind. Electron., Vol.49, No.2, pp.325-335 (2002-2)

( 4 ) L. Huber and D. Borojevic: "Space vector modulated Three-phase to threephase matrix converter with input power factor correction", IEEE Trans. IA., Vol.31, No.6, pp.1234-1246 (1995-6)

( 5 ) L. Zhang and C. Wathanasarn: "An efficient space vector modulation algorithm for AC-AC matrix converters: Analysis and implementation", IEE Power electronics and variable-speed drives, No.429, pp.108-113, Sept. (1996)

( 6 ) D.G. Holmes: "The general relation between regular-sampled Pulse-WidthModulation and space Vector Modulation for hard switched converters", in Conf. Rec. IEEE-IAS Annu. Meeting, pp.1002-1009 (1992)

( 7 ) J. Ito, I. Sato, and S. Konishi: "An improved method of input and output waveforms for the matrix converter based on virtual AC/DC/AC Conversion", SPE-02-90, IEA-02-31, pp.75-80 (in Japanese)

( 8 ) A. Ishiguro, T. Furuhashi, M. Ishida, and S. Okuma: "Output Voltage Control Method for PWM-Controlled Cycloconverters Using Instantaneous Values of Line to Line Voltages", IEEJ Trans. IA, Vol.111-D, No.3, pp.201-208 (1991-3) (in Japanese)

石黑章夫 ·古橋 武 ·石田宗秋 · 大熊 繁 : 「入力線間電圧瞬時值に 基づく PWM 制御サイクロコンバータの出力電圧制御」, 電学論 $\mathrm{D}$, 111, 3, pp.201-208 (1991-3)

( 9 ) J. Oyama, T. Higuchi, R. Tsukamoto, T. Haraguchi, E. Yamada, and T. Koga: "Steady state characteristics of PWM matrix converter", IEEJ Trans. IA, Vol.113-D, No.9, pp.1086-1093 (1993-9) (in Japanese) 小山 純・樋口 剛 - 塚本竜太 · 原口武久 ·山田英二 ·古賀高志 : 「電圧型 PWM サイクロコンバータの定常特性」, 電学論 D, 113, 9, pp.1086-1093 (1993-9)

(10) J. Oyama, X. Xia, T. Higuchi, K. Kuroki, E. Yamada, and T. Koga: "VVVF On-line control of matrix converter", IEEJ Trans. IA, Vol.116-D, No.6, pp.644-651 (1996-6) (in Japanese)

小山 純 ·夏 暁戎 ·樋口 剛 ·黑木恒二 ・山田英二 ·古賀高志 : 「PWM サイクロコンバータの VVVF オンライン制御」, 電学論 D, 116, 6, pp.644-651 (1996-6)

(11) J.K. Kang, H. Hara, E. Yamamoto, E. Watanabe, K. Yamada, and N. Sueyoshi: "The Matrix converter Drive Performance Under Input Voltage Unbalance Conditions", Proc. of IEE Japan IAS, Vol.1, pp.275-278 (2001)

(12) K.M. Sung, K. Kobayashi, and Y. Sato: "A new PWM method for instantaneous output current control of matrix converter with sinusoidal input current", ICPE2001, pp.179-183, Oct. (2001)

(13) K.M. Sung, K. Kobayashi, and Y. Sato: "A new control method to reduce input current harmonics in matrix converters", in Conf. Rec. IEEE-IAS Annu. Meeting, Vol.3, pp.1394-1402 (2002)

(14) H. Nakakoji, K. Kobayashi, K.M. Sung, and Y. Sato: "A New PWM Control Method Sinusoidal Input and Output Current Waveforms for Matrix Converters", JSPE-03-36, pp.61-66 (2003) (in Japanese)

中小路元・小林広介・成 慶珉・佐藤之彦: 「マトリックスコンバー タの入出力電流を正弦波化する PWM 制御方式の提案」, SPC-03-36, pp.61-66 (2003)

(15) N. Watanabe, K. Nunomura, K.M. Sung, and Y. Sato: "A Theoretical Investigation of Power Factor and Input Current Waveform of Matrix Converters Based on PWM Control", Proc. of IEE Japan IAS, Vol.1, pp.557-560 (2003) (in Japanese) 渡邊直人・布村和弘・成 慶珉・佐藤之彦：「PWM 制御方式を適用 したマトリックスコンバータの入力力率と入力電流波形に関する理 論的検討」, 平 15 電気学会産業応用全大 (2003) 
成慶 珉 (正員) 1970 年 5 月 28 日生。1997 年 3 月韓国朝 鮮大学電気工学修士課程修了。1999 年東京工業 大学研究生。2004 年東京工業大学大学院理工学 研究科電気・電子工学専攻博士後期課程終了, 同 年同大学工学部助手, 現在に至る。主として, 半 導体電力変換器の解析と制御方式の研究に従事。 博士 (学術)。
佐 藤 之 彦 (正員) 1963 年 9 月 3 日生。1986 年東京工業大学 工学部電気・電子工学科卒業。1988 年同大学大学 院理工学研究科電気・電子工学専攻修士課程修了。 同年同大学工学部助手 , 1996 年同助教授。2001 年千葉大学工学部助教授, 2004 年同教授, 現在に 至る。この間, 主として半導体電力变換および電 気機器に関する教育・研究に従事。博士 (工学)。

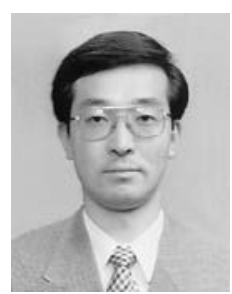

\section{中小路}

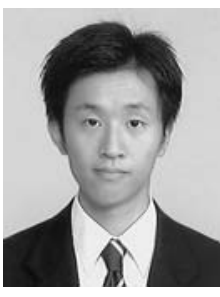

元 (正員) 1979 年 1 月 24 日生。 2001 年 3 月東京工 業大学工学部電子物理工学科卒業。2003 年 3 月 東京工業大学大学院理工学研究科電気電子工学専 攻修士課程卒業。同年 4 月東京電力 (株) 入社, 現在に至る。主として, 磁気浮上電動機駆動, パ ワーエレクトロニクスに関する研究に従事。 